\title{
Civita di Tarquinia (Comune di Tarquinia, Provincia di Viterbo, Regione Lazio).
}

The Università degli Studi di Milano began its research on the Civita di Tarquinia in 1982 under the direction of Maria Bonghi Jovino. In 1997 an assessment of past aerial photographs, geophysical prospection and a survey of the fortifications was undertaken (Bonghi Jovino, 1997; Harari, 1997, Cavagnaro Vanoni, 1997). Subsequently the investigations of the Tarquinia Project (directed since 2004 by Giovanna Bagnasco Gianni) have continued this research and focused on the excavation of a monumental complex and on the sanctuary of the Ara della Regina (Tarchna 1997, 1999, 2001, 2012) as well as studying the chronological phases of the necropolis (Marzullo 2016, 2017) and the topography of the ancient city (Marzullo 2018). In partnership with the Politecnico di Milano (Bagnasco Gianni 2014, Marzullo 2018) work has begun on a systematic study of the fortifications aimed at the reconstruction of the city enclosed within the walls (Marzullo, Piazzi 2017; Bagnasco Gianni, Garzulino \& Marzullo 2017). The research has involved the collection of all available cartography, aerial photos and LiDAR data, as well as other information obtained from historical documentation and thematic representations (from the Renaissance through to the present) to fully understand the area of the Civita. One of the most significant outcomes of a collaboration with the Soprintendenza Archeologia, Belle Arti e Paesaggio per l'area metropolitan di Roma, la provincia di Viterbo e l'Etruria meridionale has been the creation of a Geographical Information System (GIS) of the Civita with 220 site entries including several which were poorly known. Building upon the creation of this dataset, it was possible to begin to assess the geophysical surveys conducted by the Fondazione Lerici from the 1960s to the 1980s. The data had numerous difficulties for its useful application, the foremost of which was its correct topographical positioning, as well as the problems of interpreting this legacy data.

In 1964 the chance discovery of painted architectural terracottas near the Ara della Regina sanctuary suggested that an early temple may have been located in the vicinity. After several trial trenches had been unable to locate any structures, the former Soprintendente Mario Moretti requested a geophysical survey of the area following its successful application in the area of the necropolis. The reports in the archive of Fondazione Lerici show that a trial survey was undertaken in the autumn of 1964, during which only a small area was investigated. The successful results of the survey encouraged the wider inspection of the area and in 1965 Fondazione Lerici explored a further 4 hectares, with the aim of recording both elements of the city plan and investigating the existence of a temple. Several linear anomalies indicated the existence of a regular plan and subsequently 13 annual seasons were undertaken through until 1981 which covered a large part of the plateau. Alongside the excavations a number of cores were made (Levato 1985) in order to clarify the geophysical survey results. In total the survey investigated approximately 60 hectares (Fig. 1a), 600,000 measurements of the intensity of the earth's magnetic field were taken and 135 individual cores were made to confirm the buried structures. However, despite several attempts to process the magnetometry data with simple mathematical filters and for the data to be represented digitally, the overall plan had to be created with hand-drawn symbols and remained unchanged for a long time.

In the 1990s a research initiative between the Fondazione Lerici and the Institute of Mining in St. Petersburg reanalysed the data. The 600,000 magnetometry measurements of the surveys were pre-processed in order to obtain quickly and efficiently a different kind of data representation and a revised dataset where modern noise was removed. However, the reanalysis did not produce an overall synthesis of the data as it focused exclusively on limited areas, including the 'monumental complex' and the Ara della Regina sanctuary as well as highlighting some anomalies possibly related to road network (Cavagnaro Vanoni 1997; Cucarzi, Gabrielli \& Rosa 2001; Cavagnaro Vanoni 1989).

The difficulty in the interpretation of this dataset is due to several factors including the long occupation of the city, its level of conservation and the effects of modern agricultural practice (including metal fences and ploughing). The natural stone of Tarquinia also has variable 
characteristics which appear to influence the results of magnetometry. However, through a comparison of the cores and the magnetic anomalies it has been possible to demonstrate the usefulness and reliability of the dataset. Above all, the data that was collected during the initial phases of the work at the end of the 1970s, but also afterwards during the subsequent seasons of the Fondazione Lerici was difficult to position topographically. This meant that some results were removed from the final published survey even if they contained valuable information (Fig. 1, a-c). The positioning issues of the survey can be summarized as follows:

1. The Fondazione Lerici surveys were set according to magnetic North;

2. Each square of the grid drawn on the map corresponds to a predetermined linear length without factoring for the changing topography of the terrain. Therefore, the grids do not match any corresponding features on the cartography and furthermore, to produce the large-scale diagrams, the data were reduced and merged, producing further distortions.

To correctly reposition the survey, the data needs to be stretched to the topography of the site. However, due to the length of time that has passed since the surveys, the only reliable fixed points are a few monuments on the site and the output data itself of the earlier surveys. Given the importance of this dataset, which could shed new light on the urban layout of the city, and through the graphical support provided by the GIS archeological map based on the LiDAR coverage, it was decided to apply a new methodology in order to enhance the legacy data.

In collaboration with the British School at Rome, three sample blocks each of $60 \mathrm{~m}$ by $90 \mathrm{~m}$ were chosen as reference areas to locate the earlier work. The areas were subject to new gradiometry surveys which were subsequently overlaid with the previous Fondazione Lerici outputs. The new surveys were placed according to a number of criteria including areas with little modern interference, areas where anomalies were clearly distinguishable on the Fondazione Lerici outputs and areas that overlapped with previously unexplored areas, therefore increasing the overall coverage of the site.

The first sample area chosen was situated to the west on the plateau (Fig. 1, d1). The new data has allowed for the earlier work to be more securely located through the comparison of several linear anomalies in each dataset. Moreover, several rectangular anomalies were also recorded that may be associated with regularly arranged buildings, several blocks of which can be partially distinguished on the surface.

The second area chosen lay to the south-west of the Ara della Regina where the earlier campaigns of 1964 had begun (Fig. 1, d2). Similarly to the other areas, the positioning of the survey was complicated by the steep terrain below the monument. However, the new survey identified high magnetic linear anomalies that matched precisely with the results of 1965-66. This has allowed for the earlier data to be anchored in this area and for other features in the earlier outputs to be rectified (Fig. 1, c). The new data also highlights with greater clarity the form of a rectangular building in the centre of the survey area, which may be associated with the sacred structure with decorated terracottas which has yet to be identified and from where the research began in 1964.

The third area surveyed lay immediately south of the Ara della Regina (Fig. 1, d3). The new study identified a series of quadrangular structures arranged along the north-south road previously identified by the Fondazione Lerici on the eastern side of the test area. Where the magnetometry survey was extended for the first time the results indicated the likely presence of a road leading towards the temple, as well as other structures in the southwest portion of the grid.

In conclusion the new geophysical surveys, together with the GIS and archaeological evidence described above, combined with the precision and versatility of the LiDAR data, have combined to fulfil the potential of the earlier geophysical survey. It was possible to compare signs clearly associated with buried archaeological remains to the results of magnetometry and subsequently verify this data by querying the LiDAR point cloud and obtaining their position. This method has overcome the issue created by the disappearance of the topographic references used by the earlier work and the errors that occurred in rescaling the data by the earlier survey. The ability to 
precisely anchor the geophysical prospection has allowed for an initial interpretation to be made of the urban plan of the Civita di Tarquinia and for the planning of future research.

\section{Acknowledgements}

The new geophysical surveys were undertaken as part of the 'Tarquinia Project' led by the Università degli Studi di Milano under the direction of Professor Giovanna Bagnasco Gianni. The project is grateful for the fundamental support of the Soprintendenza Archeologia, Belle Arti e Paesaggio per l'area metropolitana di Roma, la provincia di Viterbo e l'Etruria Meridionale. The topographical survey was undertaken by Arch. Andrea Garzulino and Dr. Matilde Marzullo. The magnetometry survey was led by Stephen Kay (BSR Archaeological Officer) assisted by Ilaria Frumenti and was funded by a donation by Charles Williams II.

\section{References}

Bagnasco Gianni, G., 2014. Presenza/Assenza di Mura: implicazioni storico-culturali. Il caso di Tarquinia, in Mura di legno, mura di terra, mura di pietra: fortificazioni nel Mediterraneo antico, Atti del convegno internazionale (Roma 7-9 maggio 2012), eds. G. Bartoloni \& L.M. Michetti. Scienze dell'antichità, 19.2/3 - 2013, Roma, 2014, 429-53.

Bagnasco Gianni, G., A. Garzulino \& M. Marzullo, 2017. The last ten years of research at Tarquinia, in Knowledge, Analysis and Innovative Methods for the study and the dissemination of ancient urban areas, Proceedings of the KAINUA 2017 International Conference in Honour of Professor Giuseppe Sassatelli's 70th Birthday (Bologna, 18-21 Aprile 2017), eds. S. Garagnani \& A. Gaucci. Archeologia e Calcolatori 28.2, 211-21.

Bonghi Jovino, M., 1997. Le ricerche preliminari, in Tarchna 1997, 1-2.

Cavagnaro Vanoni, L., 1989. Intervento alla Civita di Tarquinia della Fondazione Lerici, in Secondo Congresso Internazionale Etrusco, Firenze 26 maggio - 2 giugno 1985, Roma, 341-45.

Cavagnaro Vanoni, L., 1997. La prospezione geofisica, in Tarchna 1997, 2-5.

Cucarzi, M., Gabrielli, D. \& Rosa, C., 2001. Gli Interventi della Fondazione Lerici all'Ara della Regina: lettura parziale del territorio circostante mediante magnetometria e carotaggi, in Tarquinia etrusca: Una nuova storia, Catalogo della mostra (Tarquinia 4 ottobre 30 dicembre 2001), ed. Sgubini Moretti A.M., Roma: L’Erma di Bretschneider, 61-5.

Harari, M., 1997. Tarquinia e il territorio suburbano nel rilevamento da alta quota: una lettura topografica, in Tarchna 1997, 5-17.

Marzullo, M., 2016. Grotte Cornetane: Materiali e apparato critico per lo studio delle tombe dipinte di Tarquinia. Tarchna suppl. 6, Milano: Ledizioni.

Marzullo, M., 2017. Spazi sepolti e dimensioni dipinte nelle tombe etrusche di Tarquinia. Tarchna suppl. 7, Milano: Ledizioni.

Marzullo, M., 2018. Tarquinia. Indagini sulle Mura, Tarchna suppl. 8, Milano: Ledizioni.

Marzullo, M. \& Piazzi, C. 2017. Attività artigianali a Tarquinia: gli spazi, le strutture e i prodotti, in Gli artigiani e la città. Officine e aree produttive tra VIII e III sec. a.C. nell'Italia centrale 
tirrenica, Atti della Giornata di Studio (British School at Rome, 11 gennaio 2016), eds. Biella, M.C., Cascino, R., Ferrandes, A.F., Revello Lami, M.. Scienze dell'Antichità 23.2, 2017, 255-72, 453.

Tarchna 1997. Bonghi Jovino, M. \& Chiaramonte Treré, C. eds. Tarquinia. Testimonianze archeologiche e ricostruzione storica. Scavi sistematici nell'abitato. Campagne 1982 - 1988, Roma: L’Erma di Bretschneider.

Tarchna 1999. Chiaramonte Treré, C. ed. Tarquinia. Testimonianze archeologiche e ricostruzione storica. Scavi sistematici nell'abitato. Campagne 1982 - 1988. I materiali 1, Roma: L'Erma di Bretschneider.

Tarchna 2001. Bonghi Jovino, M. ed. Tarquinia. Testimonianze archeologiche e ricostruzione storica. Scavi sistematici nell'abitato. Campagne 1982 - 1988. I materiali 2, Roma: L'Erma di Bretschneider.

Tarchna 2012. Bonghi Jovino, M. \& Bagnasco Gianni G. eds. Tarquinia. Il santuario dell'Ara della Regina. I templi arcaici, Roma: L'Erma di Bretschneider.

Giovanna Bagnasco Gianni, Andrea Garzulino, Stephen Kay, Matilde Marzullo, CHRISTOPHER SMITH (Università degli Studi di Milano, Politecnico di Milano, British School at Rome, Università degli Studi di Milano, British School at Rome) giovanna.bagnasco@unimi.it, andrea.grzulino@polimi.it,s.kay@bsrome.it,

Figures matilde.marzullo@unimi.it; cjs6@st-andrews.ac.uk

1a. Area covered by geophysical prospecting as published at the end of the investigation in 1997.

1b. Areas investigated in 1964-68 west of the Ara della Regina and not included in subsequent editions of the work.

1c. Results of the 19645-65 campaigns not included in subsequent editions of the work.

1d. Positioning of the sample areas and the Fondazione Lerici grid on the LiDAR data. The routes of the ancient roads are highlighted following recent work by Università degli Studi di Milano (Marzullo 2018). On the right are the results of the three areas investigated in 2017. 